Jurnal Keperawatan Silampari

Volume 5, Nomor 1, Desember 2021

e-ISSN: 2581-1975

p-ISSN: 2597-7482

DOI: https://doi.org/10.31539/jks.v5i1.2377

\title{
SIKAP REMAJA PUTRI TENTANG KANKER SERVIKS DENGAN MOTIVASI REMAJA MELAKUKAN VAKSINASI HPV
}

\author{
Putu Indah Sintya Dewi ${ }^{1}$, Luh Ayu Purnami ${ }^{2}$, Mochamad Heri ${ }^{3}$ \\ Sekolah Tinggi Ilmu Kesehatan Buleleng ${ }^{1,2,3}$ \\ indahsintya88@gmail.com ${ }^{1}$
}

\begin{abstract}
ABSTRAK
Penelitian ini bertujuan untuk mengetahui hubungan tingkat pengetahuan dan sikap remaja tentang kanker serviks dengan motivasi remaja melakukan vaksinasi HPV di SMA Negeri 1 Ubud. Jenis penelitian ini adalah penelitian kuantitatif dengan rancangan penelitian analitik pendekatan cross-sectional. Hasil analisis univariat sebagian besar responden sebagian besar siswi mempunyai tingkat pengetahuan 41 responden (42.3\%), siswi mempunyai sikap mendukung sebanyak 59 orang $(60.8 \%)$ dan siswi memiliki motivasi sedang untuk melakukan vaksinasi HPV sebanyak 71 anak (73.2\% ). Hasil penelitian ini menunjukan siswi memiliki pengetahuan cukup tentang kanker serviks dan motivasi sedang untuk melakukan vaksinasi HPV sebanyak 35 anak (36.1\%). Siswi memiliki sikap mendukung tentang kanker serviks dan motivasi sedang untuk melakukan vaksinasi HPV dengan perhitungan diperoleh nilai $r$ hitung sebesar 0,279 dan probabilitas sebesar 0,006 $(0,006<$ 0,05). Simpulan, terdapat hubungan yang signifikan antara variabel sikap remaja tentang kanker serviks dengan motivasi siswi SMA Negeri 1 Ubud kelas XI melakukan vaksinasi HPV.
\end{abstract}

Kata Kunci: Kanker Serviks, Motivasi, Pengetahuan, Sikap

\begin{abstract}
This study aims to determine the relationship between the level of knowledge and attitudes of adolescents about cervical cancer and adolescents' motivation to vaccinate HPV at SMA Negeri 1 Ubud. This type of research is quantitative research with an analytical research design with a cross-sectional approach. The results of the univariate analysis, most of the respondents, most of the students had a knowledge level of 41 respondents (42.3\%), 59 students $(60.8 \%)$ had a supportive attitude, and 71 students (73.2\%). This study showed that 35 students had sufficient knowledge about cervical cancer and moderate motivation to vaccinate HPV (36.1\%). The student has a supportive attitude about cervical cancer and is moderately motivated to vaccinate HPV with a calculated $r$-value of 0.279 and a probability of $0.006(0.006<0.05)$. In conclusion, there is a significant relationship between adolescent attitudes about cervical cancer and the motivation of eleventh graders of SMA Negeri 1 Ubud in class XI to vaccinate against HPV.
\end{abstract}

Keywords: Cervical Cancer, Motivation, Knowledge, Attitude 


\section{PENDAHULUAN}

Permasalahan kesehatan pada remaja tentu memerlukan penanganan yang menyeluruh dan terintegrasi dengan melibatkan semua unsur dan lintas sektoral (Sartika et al., 2021; Febriawati et al., 2018). Kanker serviks merupakan penyakit yang beresiko tinggi menyerang usia remaja dan menjadi penyakit kedua terbanyak pada kaum perempuan. Salah satu cara mencegah kanker serviks yang dikembangkan saat ini adalah pemberian vaksinasi Human Papiloma Virus (HPV). Dengan pemberian vaksinasi HPV diharapkan perkembangan sel - sel kanker dikendalikan, terutama di negara yang masih sulit melaksanakan program skrining. Target utama vaksinasi HPV adalah wanita yang belum aktif melakukan kontak seksual, yaitu sebelum kemungkinan terpapar HPV. Sedangkan target sekundernya adalah yang telah aktif melakukan hubungan seksual. Jika seorang wanita telah mendapatkan vaksin HPV maka mereka akan mendapatkan perlindungan infeksi HPV (Siregar \& Sunarti, 2020).

Indonesia merupakan negara dengan jumlah kejadian kanker serviks terbanyak ke empat se-Asia Tenggara. Data WHO 2018 (Information Center on HPV and Cervical Cancer) sebanyak 32.469 kasus kanker serviks atau 9,3\% dari total kasus dan diperkirakan 26 wanita meninggal setiap harinya karena kanker serviks. Menurut Depkes RI (2018) di Indonesia kanker serviks juga merupakan kanker kedua terbanyak yang menyerang wanita usia 15-44 tahun, angka kanker serviks di Indonesia mencapai 23,4 orang per 100 ribu penduduk. Rata-rata kematian akibat kanker serviks mencapai 13,9 orang per 100 ribu penduduk (Sagita \& Rohmawati, 2020).

Perkumpulan Obstetri dan Ginekologi Indonesia (POGI) cabang Bali telah mendeklarasikan "Bali Free for Servical Cancer by Year 2020” sejak tahun 2010 dengan pendidikan, penyuluhan, vaksinasi, dan see and treat. Salah satu program yang dilakukan yaitu sosialisasi tentang kesehatan reproduksi ke sekolah - sekolah dan mengadakan vaksinasi kanker serviks gratis di sekolah menengah pertama. Melalui program vaksinasi berbasis sekolah ini, tiap siswi langsung mendapatkan vaksinasi HPV subsidi langsung dari pemerintah dan pabrik penyedia vaksin kanker serviks yang menjadi mitra POGI. Sementara program berbasis sekolah ini tidak serta merta menyasar semua sekolah menengah atas, ditentukan kriteria seperti siswi berprestasi, berasal dari keluarga yang memiliki riwayat kanker serta siswi yang berasal dari keluarga kurang mampu. Menurut data dari Divisi Onkoginekologi FK Unud/RSUP Sanglah Denpasar sampai dengan 2016 di Bali capaian vaksinasi adalah 37,07\%. Dari data tersebut didapatkan bahwa masih banyak remaja putri yang belum melakukan vaksinasi HPV (Haryanti \& Mariana, 2020).

Hampir semua kasus kanker serviks dihubungkan dengan infeksi Human Papillima Virus (HPV), tingginya kasus baru kanker berkaitan erat dengan faktor resiko kanker yang sebetulnya dapat dicegah secara dini. Deteksi dini dengan melakukan pap smear secara rutin akan menghindarkan wanita dari kanker serviks dan deteksi infeksi virus HPV. Penyebab utama tingginya angka kejadian kangker serviks karena kurangnya pengetahuan, tidak melakukan vaksinasi HPV dan kurang melakukan pemeriksaan pap smear yang efektif ditujukan untuk mendeteksi pada pase lesi pre-kangker (Riawati, 2020).

Kanker serviks memiliki masa lesi pra-kangker panjang yang memberikan kesempatan mengobati sebelum berubah menjadi kanker serviks invasif. Jika seorang wanita melakukan vaksinasi HPV, maka 90\% dapat mencegah infeksi virus HPV. Vaksin HPV yang ini hanya melindungi dari HPV tipe 16 dan 18 (Purwahyuni et al., 2020).

Vaksin dapat diberikan sebagai upaya membantu pertahanan tubuh dan membasmi infeksi HPV yang sudah mulai terjadi, pemberian vaksin dapat diberikan mulai pada usia 9 tahun. Selain itu vaksin juga direkomendasikan untuk diberikan pada wanita usia 13-26 
tahun yang tidak mendapat pengulangan vaksin atau tidak mendapatkan vaksin secara lengkap. Idealnya vaksin diberikan sebelum usia rentan kontak dengan HPV yakni wanita yang akan memasuki usia seksual aktif. Vaksin HPV diharapakan dapat meningkatkan status kesehatan wanita di negara-negara berkembang karena kasus kangker serviks banyak terjadi di wilayah negara berkembang (Sari et al., 2019).

Berdasarkan data yang diperoleh dari Dinas Kesehatan Provinsi Bali ditemukan bahwa pada tahun 2015 terdapat 1741 penderita dengan 24 diantaranya meninggal karena kangker serviks. Persebaran kanker serviks di Kabupaten Gianyar pada tahun 2016 tercatat 140 penderita kangker serviks dan tahun 2017 tercatat 153 orang (Dinas Kesehatan Kabupaten Gianyar, 2018).

Rendahnya penggunaan vaksin HPV oleh masyarakat terutama remaja putri di wilayah Gianyar. Fasilitas pemerintah seperti Rumah Sakit Umum Daerah dan beberapa tempat praktik dokter spesialis kandungan telah berupaya menyediakan vaksin HPV untuk digunakan masyarakat yang berminat melalui vaksinasi. Namun vaksinasi belum sepenuhnya dilakukan oleh remaja putri. Hal ini dikarenakan kurangnya minat remaja putri melakukan vaksinasi dan biaya vaksin yang dirasa cukup mahal. Minat rendah dipengaruhi oleh beberapa faktor, antar lain pengetahuan, pengamatan, tanggapan, persepsi, dan sikap. Tingkat pengetahuan yang dimiliki remaja mempunyai andil besar dalam dorongan minat melakukan vaksinasi (Dinas Kesehatan Kabupaten Gianyar, 2018).

Berdasarkan studi pedahuluan yang dilakukan di SMA Negeri 1 Ubud pada tanggal 3 Juni 2020, didapatkan dari 15 siswi yang diwawancarai hanya 1 orang yang sudah melakukan vaksinasi HPV karena terdapat salah satu keluarga yang telah terkena kanker serviks dan 14 orang lainnya mengatakan tidak melakukan vaksinasi, itu menandakan bahwa motivasi remaja putri untuk melakukan vaksinasi HPV masih kurang. Dari 14 siswi tersebut, 9 orang tidak melakukan vaksinasi karena kurang memiliki pengetahuan tentang kanker serviks dan pencegahan melalui vaksinasi HPV serta tidak pernah mencari tahu lebih dalam tentang kanker serviks. Sedangkan 5 orang lainnya mengatakan ingin melakukan vaksinasi namun tidak dapat menjangkau biaya vaksin. Dari angka di atas dapat dilihat motivasi untuk mencegah kanker serviks melalui vaksinasi masih rendah terkait dengan pengetahuan dan sikap remaja yang masih dalam kategori kurang.

Kelebihan penelitian ini adalah belum ada penelitian sebelumnya yang lebih spesifik meneliti tentang sikap remaja putri tentang kanker serviks dengan motivasi remaja melakukan vaksinasi HPV.

\section{METODE PENELITIAN}

Jenis penelitian kuantitatif dengan rancangan penelitian analitik. Populasi dalam penelitian ini adalah semua remaja putri kelas XI yang belum melakukan vaksinasi HPV di SMA Negeri 1 Ubud sebanyak 127 anak. Penentuan sampel dengan teknik proportional simple random sampling. Sampel dalam penelitian ini adalah seluruh remaja putri kelas XI yang belum melakukan vaksinasi HPV di SMA Negeri 1 Ubud yang masuk kriteria inklusi yaitu sebanyak 97 responden. Instrumen yang digunakan dalam penelitian ini untuk mengukur tingkat pengetahuan, sikap remaja putri tentang kangker serviks dan motivasi remaja melakukan vaksinasi HPV yaitu menggunakan kuesioner.

Pada lembar kuesioner pengukuran pengetahuan tentang kangker serviks terdapat dua kolom jawaban pertanyaan yaitu benar dan salah. Nilai dari jawaban benar yaitu bernilai 1 dan nilai untuk jawaban salah yaitu bernilai 0. Kriteria hasil skor dikelompokkan menjadi tiga kategori yaitu 1. Kategori Baik: 76\%-100\%, Kategori Cukup: 56\%-75\%, dan Kategori Kurang: $<56 \%$. Pada lembar kuesioner pengukuran sikap tentang kangker serviks terdapat 
empat kolom jawaban pertanyaan yaitu sangat setuju, setuju, tidak setuju dan sangat tidak setuju. Nilai dari jawaban sangat setuju yaitu bernilai 4, 3 untuk setuju, 2 untuk tidak setuju dan nilai untuk jawaban sangat tidak setuju yaitu bernilai 1. Pada lembar kuesioner pengukuran motivasi melakukan vaksinasi HPV terdapat empat kolom jawaban pertanyaan yaitu sangat setuju, setuju, tidak setuju dan sangat tidak setuju. Nilai dari jawaban sangat setuju yaitu bernilai 4, 3 untuk setuju, 2 untuk tidak setuju dan nilai untuk jawaban sangat tidak setuju yaitu bernilai 1 .

\section{HASIL PENELITIAN}

Analisis univariat

Karakteristik Responden

Tabel. 1

Distribusi Frekuensi Responden Berdasarkan Tingkat Pengetahuan tentang Kangker Serviks

\begin{tabular}{ccc}
\hline Tingkat Pengetahuan & Frekuensi & Presentase $(\%)$ \\
\hline Baik & 32 & 33 \\
Cukup & 41 & 42.3 \\
Kurang & 24 & 24.7 \\
\hline Total & 97 & 100.0 \\
\hline
\end{tabular}

Berdasarkan tabel 1 dapat dilihat bahwa dari 97 responden sebagian besar siswi mempunyai tingkat pengetahuan cukup tentang kangker serviks 41 responden (42.3\%) dan sebagian kecil dengan tingkat pengetahuan kurang tentang kangker serviks 24 responden $(24.7 \%)$.

Tabel. 2

Distribusi Responden Berdasarkan Sikap tentang Kangker Serviks

\begin{tabular}{ccc}
\hline Sikap & Frekuensi (N) & Persentase (\%) \\
\hline Mendukung & 59 & 60.8 \\
Tidak Mendukung & 38 & 39.2 \\
\hline Jumlah & 97 & 100 \\
\hline
\end{tabular}

Berdasarkan tabel 2 dapat dilihat bahwa dari 97 responden, sebagian besar siswi mempunyai sikap mendukung tentang kanker serviks sebanyak 59 orang $(60.8 \%)$ dan siswi mempunyai sikap tidak mendukung tentang kanker serviks sebanyak 38 orang (39.2\%).

Tabel. 3

Distribusi Responden Berdasarkan Motivasi untuk Melakukan Vaksin HPV

\begin{tabular}{ccc}
\hline Tingkat Interaksi Sosial & Frekuensi (N) & Persentase (\%) \\
\hline Rendah & 13 & 13.4 \\
Sedang & 71 & 73.2 \\
Tinggi & 13 & 13.4 \\
\hline Jumlah & 97 & 100 \\
\hline
\end{tabular}


Berdasarkan tabel 3 dapat dilihat bahwa dari 97 responden, sebagian siswi memiliki motivasi sedang untuk melakukan vaksinasi HPV sebanyak 71 anak (73.2\%) dan siswi memiliki motivasi tinggi dan rendah masing-masing sebanyak 13 anak (13.4\%).

\section{Analisis Bivariat}

Tabel. 4

Data Hasil Korelasi Spearman Rank Tingkat Pengetahuan tentang Kangker Serviks dan Motivasi Melakukan Vaksinasi HPV

\begin{tabular}{|c|c|c|c|c|c|c|c|c|c|c|}
\hline \multirow{3}{*}{$\begin{array}{c}\text { Tingkat } \\
\text { Pengetahuan }\end{array}$} & \multicolumn{6}{|c|}{ Motivasi } & \multirow{2}{*}{\multicolumn{2}{|c|}{ Total }} & \multirow{3}{*}{$r$} & \multirow{2}{*}{$\rho$} \\
\hline & \multicolumn{2}{|c|}{ Tinggi } & \multicolumn{2}{|c|}{ Sedang } & \multicolumn{2}{|c|}{ Rendah } & & & & \\
\hline & $\mathrm{f}$ & $\%$ & $\mathrm{f}$ & $\%$ & $\mathrm{f}$ & $\%$ & $\mathrm{f}$ & $\%$ & & \\
\hline Baik & 6 & 18.75 & 22 & 68.75 & 4 & 12.5 & 32 & 100 & 0354 & 0000 \\
\hline Cukup & 5 & 5.2 & 35 & 36.1 & 1 & 1 & 41 & 100 & 0.534 & 0.000 \\
\hline Kurang & 2 & 2.1 & 14 & 14.4 & 8 & 8.2 & 24 & 100 & & \\
\hline
\end{tabular}

Berdasarkan tabel 4 dapat dilihat bahwa dari 97 responden, sebagian besar siswi memiliki pengetahuan cukup tentang kanker serviks dan motivasi sedang untuk melakukan vaksinasi HPV sebanyak 35 anak (36.1\%) menggunakan korelasi spearman rank dan dengan tingkat kemaknaan $(\alpha=0,05)$. Berdasarkan hasil perhitungan diperoleh nilai $\mathrm{r}$ hitung sebesar 0,354 dan probabilitas sebesar $0,000(0,000<0,05)$.

Tabel. 5

Tabel Hasil Uji Spearman Rank Sikap tentang Kanker Serviks dan Motivasi Melakukan Vaksinasi HPV

\begin{tabular}{|c|c|c|c|c|c|c|c|c|c|c|}
\hline \multirow{3}{*}{ Sikap } & \multicolumn{6}{|c|}{ Motivasi } & \multirow{2}{*}{\multicolumn{2}{|c|}{ Total }} & \multirow{3}{*}{$r$} & \multirow[b]{2}{*}{$\rho$} \\
\hline & \multicolumn{2}{|c|}{ Tinggi } & \multicolumn{2}{|c|}{ Sedang } & \multicolumn{2}{|c|}{ Rendah } & & & & \\
\hline & $\mathrm{f}$ & $\%$ & $f$ & $\%$ & $\mathrm{~F}$ & $\%$ & $f$ & $\%$ & & \multirow{3}{*}{0.006} \\
\hline Mendukung & 9 & 15.25 & 46 & 77.97 & 4 & 6.78 & 59 & 100 & \multirow{2}{*}{0.279} & \\
\hline $\begin{array}{c}\text { Tidak } \\
\text { Mendukung }\end{array}$ & 4 & 10.53 & 25 & 65.79 & 9 & 23.68 & 38 & 100 & & \\
\hline
\end{tabular}

Berdasarkan tabel 5 hasil analisis Uji Spearman Rank dapat dilihat sebagian besar yaitu $46(77,97 \%)$ siswi memiliki sikap mendukung tentang kanker serviks dan motivasi sedang untuk melakukan vaksinasi HPV hasil perhitungan diperoleh nilai $r$ hitung sebesar 0,279 dan probabilitas sebesar $0,006(0,006<0,05)$. Sehingga dapat disimpulkan bahwa terdapat hubungan yang signifikan antara variabel sikap tentang kanker serviks dengan motivasi melakukan imunisasi HPV.

\section{PEMBAHASAN}

\section{Analisis Univariat}

Berdasarkan tabel 1 dapat dilihat dari hasil penelitian tentang karakteristik responden berdasarkan pengetahuan siswi SMA Negeri 1 Ubud didapatkan bahwa sebagian besar memiliki pengetahuan dalam kategori cukup dan pengetahuan dalam kategori baik. Menurut peneliti ini dikarenakan pengetahuan siswi dipengaruhi oleh beberapa faktor diantaranya tingkat pendidikan, informasi, faktor budaya, pengalaman, umur sosial ekonomi dan minat. Pengetahuna merupakan kesan pikiran manusia sebagai hasil dari penggunaan pengindraanya. Pengetahuan akan terus bertambah dan bervariasi sesuai pengalaman yang sudah dialami. Didukung penelitian sebelumnya oleh Riawati (2020) 
menyebutkan bahwa pengetahuan responden yang termasuk kategori baik rata-rata 9 responden, cukup 8 responden dan kurang 5 responden.

Penelitian ini mendukung beberapa penelitian sejenis bahwa tingkat pengetahuan yang dimiliki remaja mempunyai andil besar dalam dorongan minat melakukan vaksinasi HPV. Untuk meningkatkan pengetahuan dan kesadaran tentang vaksiansi HPV dan kanker serviks perlu dilakukan pemberian informasi melalui promosi kesehatan (Sari et al., 2019).

Berdasarkan tabel 2 karakteristik responden berdasarkan sikap siswi tentang kanker serviks menunjukkan bahwa dari 97 siswi memberikan penilaian pada variabel sikap dalam kategori mendukung. Menurut peneliti, sikap itu suatu sindrom atau kumpulan gejala dalam merespons stimulus atau objek. Sehingga sikap itu melibatkan pikiran, perasaan, perhatian, dan gejala kejiwaan yang lain. Sejalan dengan penelitian Wantini \& Indrayani (2020) menyebutkan bahwa sikap merupakan evaluasi atau reaksi perasaan, sikap seseorang terhadap suatu objek merupakan perasaan mendukung atau memihak maupun perasaan tidak mendukung atau tidak memihak.

Berdasarkan tabel 3 dapat dilihat bahwa dari 97 responden, menunjukan penilaian pada variabel motivasi memberikan penilaian sedang. Menurut peneliti, motivasi merupakan suatu kondisi yang berbentuk dari berbagai tenaga pendorong yang merupakan desakan, dimana faktor-faktor yang dapat mempengaruhi motivasi diantaranya adalah pekerjaan, pendidikan, usia serta informasi.

Hasil penelitian ini sejalan dengan penelitian yang dilakukan oleh Siregar \& Sunarti (2020) bahwa perlu adanya informasi dalam bentuk edukasi kepada siswi tentang manfaat dari vaksinasi HPV sebagai salah satu pencegahan kangker serviks.

\section{Analisis Bivariat}

Berdasarkan tabel 4 dapat dilihat hasil penelitian bahwa dari 97 responden, berdasarkan hasil tabulasi silang didapatkan bahwa sebagian siswi yang memiliki pengetahuan cukup tentang kanker serviks dengan motivasi sedang untuk melakukan vaksinasi HPV. Serta berdasarkan hasil perhitungan diperoleh nilai $r$ hitung sebesar 0,354 dan probabilitas sebesar $0,000(0,000<0,05)$. Menurut peneliti, dengan memiliki pengetahuan maka seseorang akan lebih memahami apa yang dibutuhkan.

Hasil penelitian ini sejalan dengan penelitian yang dilakukan oleh Purwahyuni et al., (2020) menyatakan bahwa informasi kesehatan untuk melakukan vaksinasi HPV sebagian besar dalam kategori sedang yaitu 76 responden $(60.8 \%)$. Pada penelitian ini terlihat mayoritas remaja menjawab setuju pada pernyataan belum melakukan vaksinasi HPV karena tidak pernah mencari tahu tentang vaksinasi HPV.

Berdasarkan Tabel 5 dapat dilihat hasil analisis uji korelasi spearman rank menunjukkan bahwa terdapat hubungan yang signifikan antara variabel sikap remaja tentang kanker serviks dengan motivasi siswi SMA Negeri 1 Ubud keelas XI melakukan vaksinasi HPV.

Nilai $r$ hitung adalah 0,279 , artinya ada hubungan yang positif antara sikap tentang kanker serviks dengan motivasi. Dengan demikian semakin mendukung sikap siswi tentang kanker serviks maka motivasi melakukan vaksinasi HPV semakin meningkat, atau semakin tidak mendukung sikap tentang kanker serviks maka motivasi melakukan vaksinasi HPV semakin menurun. Sedangkan untuk kekuatan hubungan sikap tentang kanker serviks dengan motivasi siswi dengan hasil correlation coefficient 0,279 dinyatakan kekuatan hubungannya cukup. 
Pernyataan tersebut didukung oleh penelitian yang di lakukan Wantini \& Indrayani (2020) dengan hasil penelitian bahwa sikap remaja yang memiliki sikap positif tidak ada (0\%) yang bersedia untuk vaksinasi HPV, sedangkan remaja yang memiliki sikap positif terhadap vaksinasi HPV sebesar 47,5\% bersedia untuk vaksinasi HPV. Berdasarkan hasil uji somers" $d$, didapatkan $P$-Value $=0.000$ yang berarti ada hubungan yang signifikan antar sikap dengan kesediaan vaksinasi HPV. Besarnya korelasi 0.178 berarti sangat lemah korelasi antar sikap dengan kesediaan vaksinasi HPV.

Pernyataan tersebut didukung oleh penelitian yang dilakukan Mastikana (2021) dengan hasil bahwa dari 86 remaja putri kelas X MAN Batam sebanyak 48 siswi memiliki sikap yang positif (55.8\%) dan 38 siswi yang memiliki sikap yang negatif (44.2\%) terhadap imunisasi Vaksin HPV.

\section{SIMPULAN}

Terdapat hubungan yang signifikan antara variabel sikap remaja tentang kanker serviks dengan motivasi siswi SMA Negeri 1 Ubud keelas XI melakukan vaksinasi HPV.

\section{SARAN}

Sekolah SMA Negeri 1 Ubud untuk dapat membantu upaya peningkatan pengetahuan vaksinasi HPV dan kesediaan vaksinasi HPV dengan cara pengabdian masyarakat di sekolah. Meningkatkan program promosi kesehatan tentang pentingnya vaksinasi HPV pada remaja putri dengan bekerjasama kepada instansi kesehatan atau institusi pendidikan kesehatan. Program harus mencakup semua warga sekolah baik siswi, orang tua, staf dan guru sekolah.

\section{DAFTAR PUSTAKA}

Dinas Kesehatan Kabupaten Gianyar. (2018). Profil Kesehatan Gianyar 2018Dinas Kesehatan Kabupaten Gianyar. (2018). Profil Kesehatan Gianyar 2017. 1-202. www.diskes.baliprov.go.id. 1-202. www.diskes.baliprov.go.id

Febriawati, H., Padila, P., \& Anita, B. (2018). Pendidikan Seksual Remaja melalui Poskesja. Jurnal Pengabdian Masyarakat Bumi Raflesia, 1(1), 45-53. https://doi.org/10.36085/jpmbr.v1i1.193

Haryanti, D., \& Mariana, S. (2020). Karakteristik Wanita Usia Subur dalam Pencegahan Kanker Serviks. Jurnal Ilmiah PANNMED (Pharmacist, Analyst, Nurse, Nutrition, Midwivery, Environment, Dentist), 3(2), 100-107. https://doi.org/10.36911/pannmed.v15i3.797

Mastikana, I. (2021). Perbandingan Pengetahuan dan Sikap tentang Imunisasi Vaksin HPV pada Remaja Putri Kelas X Man dengan Remaja Putri Kelas X SMA N 5 Kota Batam. Jurnal Surya Medika, 6(2), 146-154. https://doi.org/https://doi.org/10.33084/jsm.v6i2.2132

Purwahyuni, N. M., Rismawan, M., \& Wulansari, N. T. (2020). Studi Deskriptif Hambatan Remaja dalam Melakukan Vaksinasi Human Papilloma Virus (HPV) di SMA Negeri 1 Kediri. Jurnal Riset Kesehatan Nasional, 4(2), 44-48. https://doi.org/http://dx.doi.org/10.37294/jrkn.v4i2.246

Riawati, D. (2020). Karakteristik Mahasiswa terhadap Pengetahuan tentang Vaksin Human Papiloma Virus (HPV) sebagai Imunitas Aktif Buatan. Jurnal Analis Medika Biosains (JAMBS), 7(2), 81-86. https://doi.org/10.32807/jambs.v7i2.171 
Sagita, Y. D., \& Rohmawati, N. (2020). Faktor yang Mempengaruhi Wus dalam Pemeriksaan Deteksi Dini Kanker Serviks Metode Iva. Jurnal Maternitas Aisyah (JAMAN AISYAH), 1(1), 9-14. http://journal.aisyahuniversity.ac.id/index.php/Jaman/article/view/wusyona

Sari, A. D., Lutfi, N., Syadida, H., Dirani, D., Cholifah, N., Asriningrum, T. P., Yekti, P. K., Binati, B., Cahyasari, I. A., Hidayatullah, N. S., Mulya, L. A., Firman, A. T., \& Nugraheni, G. (2019). Profil Pengetahuan dan Keyakinan Vaksinasi HPV sebagai Upaya Pencegahan Kanker Serviks pada Mahasiswi di Universitas Airlangga, Surabaya. Jurnal Farmasi Komunitas, 6(1), 14-22. https://doi.org/http://dx.doi.org/10.20473/jfk.v6i1.21824

Sartika, A., Oktarianita, O., \& Padila, P. (2021). Penyuluhan terhadap Pengetahuan Remaja tentang PKPR. Journal of Telenursing (JOTING), 3(1), 171-176. https://doi.org/https://doi.org/10.31539/joting.v3i1.2192

Siregar, D. N., \& Sunarti, S. (2020). Persepsi Ibu tentang Imunisasi Hpv pada Anak untuk Pencegahan Kanker Serviks. JUMANTIK (Jurnal Ilmiah Penelitian Kesehatan), 5(1), 34. https://doi.org/10.30829/jumantik.v5i1.6426

Wantini, N. A., \& Indrayani, N. (2020). Low Willingness to Participate in HPV Vaccination among Adolescent Girls. Jurnal Kebidanan Indonesia, 11(1), 69-78. https://doi.org/https://doi.org/10.36419/jkebin.v11i1.327

Wantini, N. A., \& Indrayani, N. (2020). Kesediaan Vaksinasi HPV pada Remaja Putri Ditinjau dari Faktor Orang Tua. Jurnal Ners Dan Kebidanan (Journal of Ners and Midwifery), $7(2)$,

213-222. https://doi.org/https://doi.org/10.26699/jnk.v7i2.ART.p213-222 